\title{
Ecotourism Development Potential in Sirah Pulau Padang Sub-district Reviewed from the Society Plantation Sector
}

\author{
Ari Sugiarto \\ Email: sugiartoari13@gmail.com
}

\begin{abstract}
Each region has the potential to be developed into an ecotourism area. Ecotourism development in an region have a large impact on a region. One sector that has the potential to be developed into an ecotourism area, namely plantations. Sirah Pulau Padang Sub-district has quite extensive plantations. Research needs to be done to see the development potential of ecotourism in Sirah Pulau Padang Sub-district in terms of the society plantation sector. This research was carried out by observing society plantations and associated with the ecotourism development potential. The results of the research show that in Sirah Pulau Padang Sub-district has the potential to be developed into a seasonal ecotourism area.
\end{abstract}

Keywords: Ecotourism, Sirah Pulau Padang Sub-district, Plantations

\section{Introduction}

Ecotourism development in a region can help in rural society development, biodiversity conservation, conservation education (Eshun, 2010), cultural conservation, (Friedman, 2009), and economic improvement (Ummiroh and Rini, 2013).

Each region has its own ecotourism potential that can be developed. The ecotourism development will have a major impact on the progress of a region. According to Klak (2007), one of the potentials that can be developed for ecotourism is agriculture. In addition, the plantation sector can also be developed into an ecotourism area.

Sirah Pulau Padang Sub-district is one of the Sub-districts in Ogan Komering Ilir District, South Sumatra Province. According to Sugiarto (2018), Sirah Pulau Padang Sub-district consists of several ecosystems, namely plantations, rice fields, rivers and settlements. Seeing of existence ecotourism development potential in the plantation sector, Research needs to be on ecotourism development potential in Sirah Pulau Padang Sub-district reviewed from the society plantation sector. The benefits of this research can provide data on ecotourism development potential in Sirah Pulau Padang Sub-district.

\section{Research Methods}

The research was conducted in December 2018 in Sirah Pulau Padang Subdistrict, Ogan Komering Ilir District, South Sumatra. This research was conducted by observing on society plantations. The observation variables are the types of plants planted and the potential to support ecotourism development and the estimated harvest season. After obtaining the observed variables, it is associated with ecotourism development potential.

\section{Results and Discussion}

The results of observations on society plantations obtained plants that have the potential to support ecotourism development, namely: 
Table 1. Types of plants planted on society plantations and estimated harvest season

\begin{tabular}{|c|c|c|}
\hline Plants & Local name & Estimated harvest season \\
\hline $\begin{array}{l}\text { Durio zibethinus Rumph. ex } \\
\text { Murray }\end{array}$ & Duren & December-January \\
\hline Lansium domesticum Corr. & Duku & February-March \\
\hline Garcinia mangostana $\mathrm{L}$. & Mangges & December-January \\
\hline Nephelium lappaceum L. & Rambutan & January-February \\
\hline $\begin{array}{l}\text { Baccaurea motleyana Müll. } \\
\text { Arg. }\end{array}$ & Rambai & January-February \\
\hline Bouea macrophylla Griff. & Raman, Ganderie & January-February \\
\hline
\end{tabular}

Ecotourism development potential in Sirah Pulau Padang Subdistrict if viewed from the society plantation sector has the potential to develop seasonal ecotourism. Based on observations on society plantations, this seasonal ecotourism can take place from December to March. Seasonal ecotourism activities can be filled with several activities such as camping in farming, outbound, enjoying fruits, or learning gardening from the community. These activities can all be carried out in one ecotourism visit in Sirah Pulau Padang Subdistrict. Guides of ecotourism activities are of course from educated local communities, this is so that ecotourism guides have a lot of knowledge about the surrounding environment and provide convenience in communicating with ecotourism. In addition, the society can provide souvenirs for ecotourism which can be in the form of harvested fruits or handmade by the society. The society can also ask for input and advice from ecotourism after participating in ecotourism activities to improve ecotourism in Sirah Pulau Padang Subdistrict. According to Klak (2007), several ways to develop tourism activities can become a fundamental part of integrated regional development such as by promoting healthy local agriculture, land, expertise, professional skills development, job diversification, solidarity and community pride. According to Sugiarto and Hanifa (2018), Lansium domesticum Corr. which is found in Ogan Komering Ilir District, commonly known as duku komering. This can be another attraction for developing ecotourism in Sirah Pulau Padang Subdistrict.

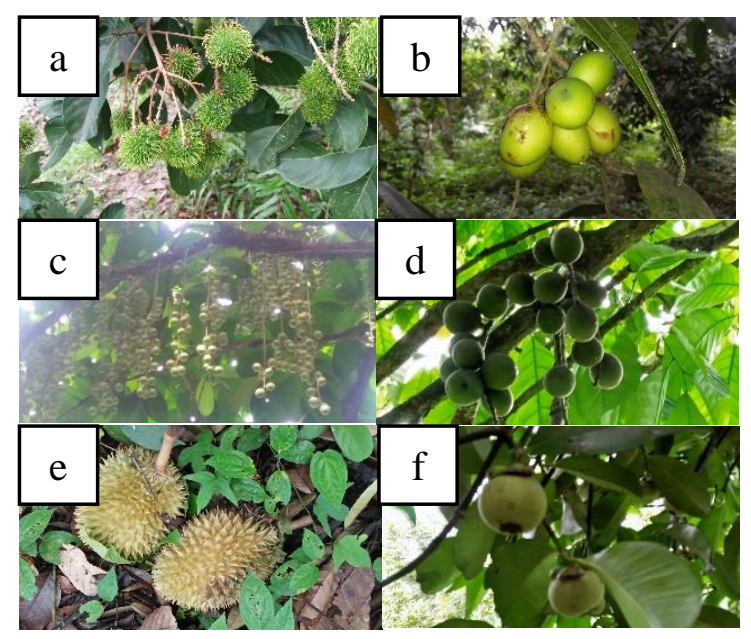

Figure 1. Fruit a. Nephelium lappaceum, b. Baccaurea motleyana, c. Bouea macrophylla, d. Lansium domesticum, e. Durio zibethinus, and f. Garcinia mangostana

Ecotourism development in Sirah Pulau Padang Sub-district can be carried out faster with government intervention, in this case the government can help provide funds for the construction of supporting facilities for ecotourism activities and assist in promoting ecotourism activities in Sirah Pulau Padang Sub-district. Implementation of ecotourism activities in Sirah Pulau Padang Sub-district can help improve the economy of the society. This is supported by Eshun (2010), ecotourism development can contribute to rural society development, biodiversity conservation and conservation education. According to Ummiroh and Rini 
(2013), ecotourism not only increases economic value but has added value. In addition, according to Friedman (2009), the benefits of ecotourism development are expected to help development, provide environmental protection, and cultural conservation. But, according to Tran and Do (2011), the existence of ecotourism in a region can cause many negative impacts on natural resources, ecology, and the local environment.

\section{Conclusion}

Ecotourism development potential in Sirah Pulau Padang Sub-district if reviewed from the society plantation sector is very support to be development into a seasonal ecotourism area. Plants that are widely planted on society plantations are Durio zibethinus, Lansium domesticum, Garcinia mangostana, Nephelium lappaceum, Baccaurea motleyana, and Bouea macrophylla which have seasonal fruit. When visiting seasonal ecotourism in Sirah Pulau Padang Sub-district can take place from December to March.

\section{References}

Eshun, G. 2010. Ecotourism Development in Ghana: A Postcolonial Study with Focus on Boabeng-Fiema Monkey Sanctuary and Kakum National Park. Tesis. University of Leicester, Department of Geography.

Friedman, V.S. 2009. Ecotourism in Dominica: Studying the Potential for Economic Development, Environmental Protection and Cultural Conservation. Island Studies Journal. 4(1): 3-24.

Klak, T. 2007. Sustainable Ecotourism Development in Central America and the Caribbean: Review of Debates and Conceptual Reformulation.
Geography Compass. 1(5): 1037-1057.

Sugiarto, A. 2018. Inventarisasi Belalang (Orthoptera: Acrididae) di Perkebunan dan Persawahan Desa Serdang Menang, Kecamatan Sirah Pulau Padang, Kabupaten Ogan Komering Ilir. (Online). https://doi.org/10.31227/osf.io/ dqprh. Accessed on January 1, 2019.

Sugiarto, A dan Hanifa, M. 2018. Ekologi Duku Komering. (Online) https://doi.org/10.31220/osf.io/ g6fsd. Accessed on January 1, 2019.

Tran, H.M.L and Do, Q.A. 2011. Impact of Ecotourism: A Study on the Environmental Impact of Ecotourism in Can Gio Mangrove Biosphere, Vietnam. Skripsi. Laurea University of Applied Sciences, Department of Hospitality Management.

Ummiroh, I.R and Rini, H. 2013. AgroEcotourism Management through Cooperative Based Coffee Plantation Commodity to Increase Welfare of Coffee Farmer. Journal of Economics, Business and Management. 1(4): 347-349. 